\title{
Is Ten Years a Life Review?
}

\author{
Nancy Evans Bush, M.A. \\ International Association for Near-Death Studies \\ (IANDS)
}

ABSTRACT: Looking back on ten years of involvement with near-death studies and with the International Association for Near-Death Studies, I review some of the major questions and accomplishments of that decade both in our understanding of the near-death experience and in our service as an organization.

It was only a one-inch ad in the Sunday classifieds of the Hartford Courant, advertising for a job description I didn't particularly want"office manager"-in a field I'd never heard of-something called "neardeath studies." But a commute to the University of Connecticut would be short, the idea of learning something new was intriguing, and in that mid-winter of 1981, I did need to find a job. Besides, the position promised to be temporary.

So much for temporary. When Bruce Greyson asked me to write a brief retrospective for the Journal's tenth anniversary, it was with the observation that as the two players from those early days who are still somehow involved with IANDS administration, he and I have taken on relic status. He worded it more tactfully than this, of course, but the

Nancy Evans Bush, M.A., is a free-lance writer, editor, and consultant on doctoral dissertations, and has a private practice in pastoral counseling. Ten years ago she was IANDS' first Executive Director; she now serves on its Board of Directors as President. Reprint requests should be addressed to Ms. Bush at P.O. Box 9486, Bolton, CT 06043 . 
shock remained: one old codger talking to another. What, Bruce asked, could I say about my observations over these years?

What was it like in the olden times, when every phone call was apt to begin, "I hope you won't think I'm crazy, but ..." and television interviews were still a novelty? What was it like, crossing the limitless plains of academic disbelief and media landrush toward what seemed a golden promise for humanity? Bumpy, that's what it was like (and still is, sometimes). What was it like, when we were laid-back and full of talk, when everyone had questions? Questions ran on endless as high desert, their answers muddy as swamps. Having floundered through, we have begun to see progress, sometimes even settlement near old sloughs.

\section{The Frontier}

One question, addressed in early Journal articles but still unclear in popular thinking, is represented by the unhappy plight of the physician whose patient announced weeks after a successful and apparently uneventful procedure that a malpractice suit was pending. The reason? "The doctor said everything went great; but I know better, because I had this near-death experience. He never told me I was dead. There's a cover-up. I must be really sick, and he's trying to hide that something went wrong." This is a true story, and not the only one of its kind.

If the experiencer was not near death, was it a near-death experience? We don't have the words quite right yet. "Near-death experience" ("NDE") worked just fine for that first group of Raymond Moody's accounts, and it remains a precise term in appropriate circumstances. Being close to death does constitute, as Ken Ring puts it, "a reliable trigger" for the experience. The lingering semantic difficultyactually, it's the great semantic impossibility -is that the great majority of experiencers were not clinically dead at the time of the event. A rough survey of the IANDS archives some six years ago indicated that perhaps 10 percent of the writers reported having been declared clinically dead, with the remainder stating vaguely that "something happened" during a routine medical procedure, childbirth, drug incident, accident, illness, or great personal stress, but with no cessation of vital signs and little or no indication of genuine threat to life. So, then, are these "near-death" experiences? Semantically, they can't be; on the other hand, we have no other term for them.

In fact, it now seems that The Experience is the experience, by whatever title. What varies is the manner of its precipitation; obviously, there is no single trigger. Childbirth experiences, trauma expe- 
riences, drug experiences, clinical death experiences, meditational experiences, and others share identically the pattern, the intensity, the insight, the aftereffects-all that we call the "near-death experience." Would a different name be desirable? Probably. Are we apt to find one? Probably not, if only because "near-death experience" is so widely recognized and so firmly established in public consciousness. Some dilemmas continue.

A few questions have been resolved. There was, for example, the hotly-debated matter of whether it would be safe to assemble a large group of near-death experiencers in the same room. Given the high psychic energy of experiencers, especially when talking about their NDEs, what might happen? Speculations escalated. Perhaps we should have back-up generators in case the lights blew, or spiritual emergency trauma teams for emotional storms. Perhaps the entire room would vibrate. (Daydream: Perhaps the vibrations would increase, whining like high-tension wires, moving to a spin until at last the entire group, wrenched from the building by the sheer intensity of their energies, would rise disappearing into the sky like a wheel of light.) Well, there was time for such fancies when we were first on the road. IANDS has now had ten conferences but no generators, no ambulances, no melt-down. High energy, yes, but the lights stay on.

We know now that children do indeed have experiences every bit as powerful as those of adults, and that they may remember an NDE from infancy all their lives. The imagery produced in a childhood experience may be astounding, both in its detail and its archetypal features. Some youngsters seem to have a difficult time afterwards emotionally and psychologically; this unwelcome revelation mirrors the recognition that adult experiencers, too, may find an NDE costly.

Among the discoveries of the past ten years is that answers aren't necessarily as simple as they seem. Oh, the really big questions have simple answers; it's just getting from here to there that's complicated. Aftereffects, for example: Isn't it wonderful to have been in the Light? Isn't it desirable to understand compassion, be unafraid of death, hold non-materialistic values, perhaps to discover enhanced intuitive abilities? After a decade, we can say, "Maybe." We now know there's a price.

The price paid by a great many experiencers is high. It may include long-term depression, broken relationships, disrupted career, feelings of severe alienation, an inability to function in the world, long years of struggling with the keen sense of altered reality. Divorce appears to be a frequent aftereffect; although reliable statistics are lacking, I have heard figures as high as $\mathbf{7 5}$ percent. Although the most disabling aftereffects seem to affect a minority of experiencers, for them the 
impact is severe, and effective interventions remain hard to find. The questions do not end.

Some of us are now struggling to find language with which to discuss frightening near-death experiences. Are they truly rare, or is the scarcity of reports a product of experiencers' reluctance to acknowledge having had such an experience? Deep in our cultural assumptions is the equation that pleasure $=$ heaven $=$ reward $=$ psychologically healthy/ positive (good) person and its corollary, pain =hell=punishment $=p s y$ chologically unhealthy/negative (bad) person. Despite the lack of evidence to support the value relationship so casually drawn, this curious judgmentalism seems bred into us like milk production into Holsteins. How many people struggling with a terrifying NDE are apt to bring their vulnerability into this public arena? And what will we say to them, anyway? The issue may be the Rockies of the voyage. Without the attempt, through, the field of near-death studies will describe only a piece of its whole.

Still on the scene where Gulliver found them are the Laputans (a group of philosophers so ethereal in their interests that they tended to float away if not restrained) and the Lagodans (scientists so materially bound they could barely look up, who couldn't float if they tried). Well, some of the latter remain locked in knee-jerk responses, foaming on cue at the suggestion that scientific materialism lacks some answers and is ill-equipped to deal with questions of meaning and value. "The NDE? It's only ... only a physiological response . . . only psychological ... only hallucination...," and anything but the reductionist view is "bunk, hokum, and poppycock!" At another extreme, their opposition, whom I shall term neo-Gnostics, apparently regretting the existence of physical form and process, speaks only of "higher" thingshigher consciousness, higher self, higher metaphysics. Somewhere in between, the work of the world goes on, and we begin to recognize that a deeply moving experience, pregnant with spiritual meaning, may be seeded by a physiological mechanism. Everything is interconnected; wonders abounding.

\section{At the Homestead}

As for IANDS itself, the road has been no less bumpy. It may have been more rut-filled than that of the research, because whereas the work of theoretical inquiry tends to be solitary, the work of organizations involves lots of personalities and many types of constraint.

That ad in the Courant took me to a little windowless box, which was 
IANDS' home at the University, inhabited like a Hobbit hole by student volunteers. It was a one-file-cabinet operation, but what a time of excitement, with everything promising and new and Ken Ring bouncing in every day to see how things were going. Bruce Greyson was still at the University of Michigan; Steve Straight (another of the veterans, behind the scenes) was already managing editor of the journal while working on his Master's degree; Michael Sabom's Recollections of Death was still a year away. Within two years, the office boasted four file cabinets and had work-load problems that are still troublesome.

For everyone involved with its inner workings, IANDS has constituted a perpetual enigma. I'm convinced it's a spiritual exercise. There's a Zen saying, "Before Enlightenment: chop wood and carry water. After Enlightenment: chop wood and carry water." It's easy enough to nod wisely at that; the real trick is to live it.

Somehow, the expectation has persisted that IANDS is supposed to be different. After all, don't we know about the Light? Aren't IANDS people filled with unconditional love and Knowing? Sure, but everyone is still on the trail, no one yet past personal issues and Shadow. The human condition still operates, and the challenge remains discovering how to translate the belief in unconditional love into professionalism; learning that Knowing doesn't mean one has all the answers; and finding the system by which at the organizational level-subject content notwithstanding-IANDS can operate as a business. This is a test: chop wood; carry water.

Meanwhile, I rejoice in the miracle of IANDS' persistent demonstration that beyond near-death there is life abundant. I rejoice in all the Journal contributors who have worked to frame the questions and to hazard answers, and in the readers who have responded. But mostly, just now, I rejoice in and honor the years of quiet, behind-the-scenes labor of editors Bruce Greyson and Steve Straight, whose patience has been tested more times and in more ways than are rationally imaginable; whose perseverance rivals that of Sisyphus; and whose dedicated skill has kept the wood chopped, the water carried, and their wagon rolling, making possible this tenth anniversary issue of the Journal of Near-Death Studies. 